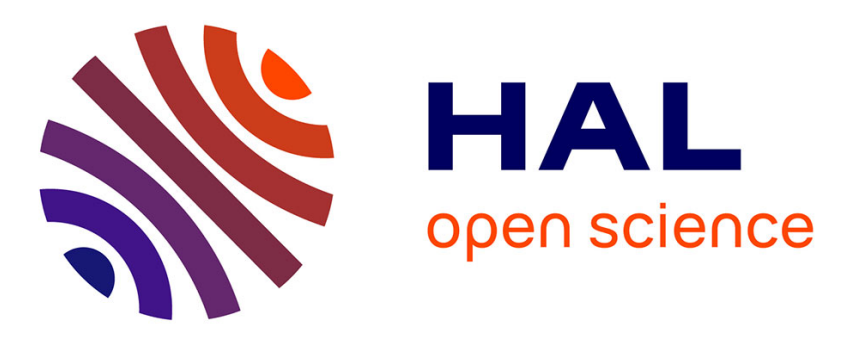

\title{
Direct borohydride fuel cells: A selected review of their reaction mechanisms, electrocatalysts, and influence of operating parameters on their performance
}

Alexandr Oshchepkov, Antoine Bonnefont, Gaël Maranzana, Elena R Savinova, Marian Chatenet

\section{To cite this version:}

Alexandr Oshchepkov, Antoine Bonnefont, Gaël Maranzana, Elena R Savinova, Marian Chatenet. Direct borohydride fuel cells: A selected review of their reaction mechanisms, electrocatalysts, and influence of operating parameters on their performance. Current Opinion in Electrochemistry, 2022, 32, pp.100883. 10.1016/j.coelec.2021.100883 . hal-03494479

HAL Id: hal-03494479

https://hal.univ-grenoble-alpes.fr/hal-03494479

Submitted on 19 Dec 2021

HAL is a multi-disciplinary open access archive for the deposit and dissemination of scientific research documents, whether they are published or not. The documents may come from teaching and research institutions in France or abroad, or from public or private research centers.
L'archive ouverte pluridisciplinaire HAL, est destinée au dépôt et à la diffusion de documents scientifiques de niveau recherche, publiés ou non, émanant des établissements d'enseignement et de recherche français ou étrangers, des laboratoires publics ou privés. 
Direct borohydride fuel cells: a selected review of their reaction mechanisms, electrocatalysts and influence of operating parameters on their performance.

Alexandr Oshchepkov ${ }^{1}$, Antoine Bonnefont ${ }^{2}$, Gaël Maranzana ${ }^{3}$, Elena R. Savinova ${ }^{4}$ and Marian Chatenet ${ }^{5} \dagger$

${ }^{1}$ Boreskov Institute of Catalysis, 630090 Novosibirsk, Russia

${ }^{2}$ Institut de Chimie de Strasbourg, UMR 7177 CNRS-University of Strasbourg, 67070

Strasbourg, France

${ }^{3}$ Université de Lorraine, CNRS, LEMTA, UMR 7563, 54504 Vandoeuvre Les Nancy, France

${ }^{4}$ Institut de Chimie et Procédés pour l'Energie, l'Environnement et la Santé, UMR 7515

CNRS-University of Strasbourg, 67087 Strasbourg Cedex, France

${ }^{5}$ Univ. Grenoble Alpes, Univ. Savoie Mont Blanc, CNRS, Grenoble INP (institute of engineering, Univ. Grenoble Alpes), LEPMI, 38000 Grenoble, France

$†$ Corresponding author:

Tel.: +334 768265 88; E-mail address: marian.chatenet@ grenoble-inp.fr 


\begin{abstract}
:
Direct borohydride fuel cells (DBFC) oxidize an easily-stored energy-dense borohydride fuel (sodium borohydride: $\mathrm{NaBH}_{4}$ ), that in theory reacts $c a .400 \mathrm{mV}$ below $\mathrm{H}_{2}$ and produce 8 electrons per $\mathrm{BH}_{4}{ }^{-}$anion. However, the borohydride oxidation reaction (BOR) does not fully meet these promises in practice: the electrocatalyst nature, structure and state-of-surface, and the operating conditions ( $\mathrm{pH}, \mathrm{BH}_{4}{ }^{-}$concentration, temperature, fluxes) noticeably influence the BOR kinetics and mechanism. Nickel and platinum-based catalysts both have assets for the BOR. DBFCs can only yield decent performance if their separator combines high ionconductivity and efficient separation of the reactants; cation-exchange membranes, anionexchange membranes, bipolar membranes and porous separators all have their own advantages and drawbacks. Besides the anode, the choice of separator must consider the DBFC cathode reaction, where oxygen (air) or hydrogen peroxide are reduced, provided adapted catalysts are used. All these aspects drive the DBFC performance and stability/durability.
\end{abstract}

Keyword: Borohydride Oxidation Reaction; Direct Borohydride Fuel Cells; Platinum; Nickel; Palladium; Hydrogen escape 


\section{Highlights:}

- The BOR kinetics/mechanism strongly depends on the catalyst and operating parameters

- Metallic nickel is highly efficient at low potential values but leads to high $\mathrm{H}_{2}$ escape

- Platinum leads to fast kinetics of the $\mathrm{H}_{2}$ production from $\mathrm{BH}_{4}{ }^{-}$and fast $\mathrm{H}_{2}$ oxidation

- Depending on the membrane/separator, $\mathrm{DBFC}$ must employ $\mathrm{BH}_{4}{ }^{-}$tolerant cathodes

- The morphology of the electrode, diffusion medium and bipolar plate channels impact mass-transport hence DBFC performance 


\section{Introduction}

Direct borohydride fuel cells (DBFC) increasingly stimulate the scientific community since two decades, following the pioneering work of Amendola et al. [1]. DBFCs oxidize a borohydride fuel (e.g. sodium borohydride: $\mathrm{NaBH}_{4}$ ) at their anode [2], fed as alkaline anolyte $\left(\mathrm{BH}_{4}{ }^{-}\right.$is only stable at high $\mathrm{pH}$ [3]). The borohydride oxidation reaction (BOR, Eq.1) produces 8 electrons per $\mathrm{BH}_{4}{ }^{-}$anion in theory, and its equilibrium potential (-0.41 V vs RHE) is $400 \mathrm{mV}$ below the equilibrium potential of the hydrogen electrode, the latter being the anode in $\mathrm{H}_{2}$-fed fuel cells [4]. This grants DBFC high theoretical energy-density and explains their interest to power portable electronic or small mobility devices. However, this low theoretical operating potential induces drawbacks: depending on the anode electrocatalyst, the BOR may compete with the electrochemical hydrogen evolution (HER) and hydrogen oxidation (HOR) reactions, and with the heterogeneous borohydride hydrolysis. Hence, proper anode catalyst and structure must be selected for a DBFC anode; Section 2 summarizes recent achievements on the theme, by focusing in particular on catalysts for which recent progresses in the understanding of the reaction mechanism were made. To efficiently separate DBFC reactants, an operating cell shall employ a properly-designed separator (Section 3), but also a dedicated cathode catalyst; the choice of these materials must be adapted to the cathode reaction: (gaseous) oxygen reduction reaction, ORR, in a classical DBFC (Eq.2), or (acidic liquid) hydrogen peroxide reduction reaction, HPRR, in a so-called $\mathrm{H}_{2} \mathrm{O}_{2}$-DBFC (Eq.3) (Section 4). In complete DBFCs, the interplay between these components and their morphology, structure and assembly is critical to the overall cell performance (Section 5).

$$
\begin{gathered}
\mathrm{BH}_{4}^{-}+8 \mathrm{OH}^{-} \rightarrow \mathrm{B}(\mathrm{OH})_{4}^{-}+4 \mathrm{H}_{2} \mathrm{O}+8 \mathrm{e}^{-} \\
\quad \mathrm{BOR}, E^{0}=-0.41 \mathrm{~V} \text { vs } \mathrm{RHE}, \mathrm{pH} 14=-1.24 \mathrm{~V} \text { vs } \mathrm{SHE} \\
\mathrm{O}_{2}+2 \mathrm{H}_{2} \mathrm{O}+4 \mathrm{e}^{-} \rightarrow 4 \mathrm{OH}^{-} \\
\mathrm{ORR}, E^{0}=1.23 \mathrm{~V} \text { vs RHE, pH } 14=0.401 \mathrm{~V} \text { vs SHE } \\
\mathrm{H}_{2} \mathrm{O}_{2}+2 \mathrm{H}^{+}+2 \mathrm{e}^{-} \rightarrow 2 \mathrm{H}_{2} \mathrm{O}
\end{gathered}
$$

HPRR, $E^{0}=2.60 \mathrm{~V} v s$ RHE, $\mathrm{pH} 0=1.77 \mathrm{~V} v s \mathrm{SHE}$

Several papers have already reviewed the DBFC operation and various components of the system [4-6]. Here, special attention is devoted to recent papers mainly dealing with the BOR electrocatalysts and their reaction mechanisms, as well as the influence of cathode electrocatalysts, separators and operating parameters on the DBFC performance. 


\section{The borohydride oxidation reaction (BOR) at the DBFC anode}

\subsection{Electrocatalytic activity of different metals in the BOR}

Choosing a proper DBFC anode is crucial to the fuel cell performance. Various materials have been investigated as potential BOR catalysts in full DBFC and in half-cell configuration [4]. This section focuses on $\mathrm{Pt}, \mathrm{Pd}, \mathrm{Au}$ and $\mathrm{Ni}$ catalysts, whose individual BOR performance have been studied fairly comprehensively, and for which the mechanisms and kinetics of reaction are rather consensual. To correctly evaluate the BOR activity of anode catalysts, the measurements are typically conducted in electrochemical half-cells, using rotating disk electrodes (RDE). RDE allows to separately study the anode reaction, control its mass-transport and effectively remove the $\mathrm{H}_{2}$ gas bubbles generated at the working electrode (preventing the blocking of the active sites surface). Since the BOR involves the formation of adsorbed intermediate species [7], BOR activities on various metallic surfaces must be compared for similar electrochemically-active surface area (ECSA), $\mathrm{NaBH}_{4}$ concentration and electrode rotation rate.

Figures $1 \mathrm{~A}$ and B compare the BOR activities of carbon-supported metal nanoparticles $(\mathrm{Ni} / \mathrm{C}$, $\mathrm{Pt} / \mathrm{C}, \mathrm{Pd} / \mathrm{C}$ and $\mathrm{Au} / \mathrm{C}$ ) in $5 \mathrm{mmol} \mathrm{L}^{-1} \mathrm{NaBH}_{4}$ and $1 \mathrm{~mol} \mathrm{~L}^{-1} \mathrm{NaOH}$ in a narrow and a wide potential interval, respectively. The $\mathrm{Au} / \mathrm{C}$ electrode demonstrates negligible BOR current below ca. $0.3 \mathrm{~V}$ vs RHE, requiring application of high potentials (above $0.8 \mathrm{~V}$ vs RHE) to achieve mass-transport limiting current. On Pd/C, the BOR starts at $c a .0 .3 \mathrm{~V}$ lower potential than for $\mathrm{Au} / \mathrm{C}$, but the BOR current is still negligible below $0 \mathrm{~V} v s \mathrm{RHE}$. For Pt/C, the BOR current increases abruptly around $0 \mathrm{~V}$ vs RHE, but the HER becomes predominant and limits the BOR efficiency below $c a$. $-0.05 \mathrm{~V}$ vs RHE. In contrast, metallic Ni/C exhibits anodic BOR currents already above $-0.2 \mathrm{~V}$ vs RHE, although the mass-transport limiting current on $\mathrm{Ni} / \mathrm{C}$ is lower than on Pt/C (Figure 1A). Albeit not relevant to DBFC applications, the BOR has also been investigated at high anodic potentials (Figure 1B): formation of surface oxides upon anodic polarization results in attenuated $\mathrm{BOR}$ activity of $\mathrm{Pt}, \mathrm{Pd}, \mathrm{Au}, \mathrm{Ni}$, due to decreased number of surface sites available for $\mathrm{BH}_{4}{ }^{-}$adsorption. The strongest effect was observed for $\mathrm{Ni}$ (and $\mathrm{Ni} / \mathrm{C}$ ): an electrode passivated after applying potentials exceeding $0.5 \mathrm{~V} v s$ RHE [8] (denoted as $\mathrm{NiO}_{x} / \mathrm{C}$ in Figure 1B), becomes inactive towards low-potential BOR and catalytically-active only above ca. $1.3 \mathrm{~V}$ vs RHE, where $\mathrm{NiOOH}$ species form ${ }^{1}$ [8]. Partially oxidizing the Ni

1 The current increase observed above $c a .1 .5 \mathrm{~V}$ vs RHE comprises both the high-potential BOR and the oxygen evolution reaction (OER) contributions. 
surface not only decreases the BOR currents, but also significantly increases the open-circuit potential (OCP, the potential reached at zero current) compared to metallic Ni (Figure 1C). The latter can be attributed to decreased binding-energy of $\mathrm{H}_{\mathrm{ad}}$ on metallic $\mathrm{Ni}$ adjacent to the $\mathrm{NiO}_{x}$, sites and ensuing increased rate of the HER competing with the BOR below $0 \mathrm{~V}$ vs RHE [9]. This example underscores how precisely-controlled surface state is needed to reach high BOR activity, notably for reactive metals like Ni.

By comprehensively-analyzing published data (comparing potentials required to reach a relevant current density, RDE configuration), Olu et al. benchmarked BOR activity of various materials [4]. Figure 1D updates such plot, constructed from low- $\mathrm{NaBH}_{4}$-concentration data (5 or $10 \mathrm{mmol} \mathrm{L}^{-1}$ in most studies) for carbon-supported nanoparticles: Ni clearly outperforms all other catalysts (including $\mathrm{Pt}$ ) at low potentials. Other conditions being equal, higher overpotentials are required to achieve reasonable BOR current on 'smooth' polycrystalline electrodes due to their much lower ECSA (Figures 1D versus 2B). 

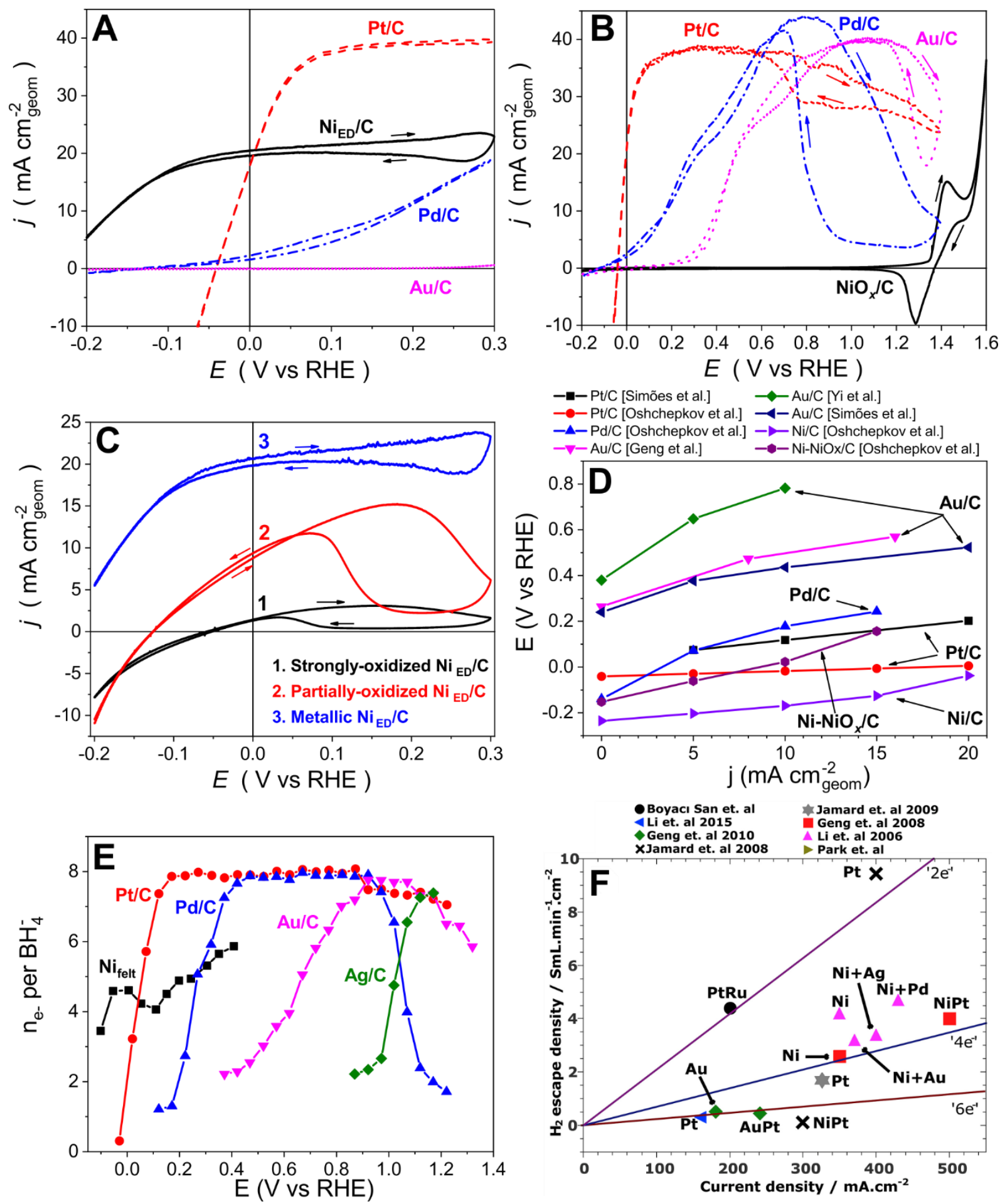

Figure 1. Ohmic drop-corrected (in dynamic mode) CV curves (A), (B) obtained for metallic $\mathrm{Ni}_{\mathrm{ED}} / \mathrm{C}$ or oxidized $\mathrm{NiO}_{x} / \mathrm{C}$ ( solid curve), $\mathrm{Pt} / \mathrm{C}$ (dashed curve), $\mathrm{Pd} / \mathrm{C}$ (dash-dotted curve), and $\mathrm{Au} / \mathrm{C}$ (dotted curve), as well as for $(\mathrm{C}) \mathrm{Ni}$ saturated $1.0 \mathrm{~mol} \mathrm{~L}-1 \mathrm{NaOH}+5 \mathrm{mmol} \mathrm{L}^{-1} \mathrm{NaBH}_{4}$ at $v=20 \mathrm{mV} \mathrm{s}^{-1}$ and $\omega=1600 \mathrm{rpm}$; reproduced from [9] with permission from the American Chemical Society. (D) Review of RDE characterization of BOR for carbon-supported nanoparticles; replotted from [10] with permission from Elsiever. Data were taken from Simoes et al. [11], Yi et al. [12], Geng et al. 
[13], and Oshchepkov et al. [9]. (E) number of electrons valorized during the BOR, recalculated from DEMS measurements; replotted from [14] with permission from the American Chemical Society. (F) Hydrogen escape measured in a DBFC configuration and plotted against the current density; reproduced from [10] with permission from Elsevier. Data were taken from Boyac1 San et al. [15], Li et al. [16, 17], Geng et al. [13, 18], Jamard et al. [19, 20] and Park et al. [21].

The OCP value varies as: $\mathrm{Ni} / \mathrm{C}<\mathrm{Pd} / \mathrm{C}<\mathrm{Pt} / \mathrm{C}<\mathrm{Au} / \mathrm{C}$ and below $0 \mathrm{~V}$ vs $\mathrm{RHE}$ is determined by competition between the HER (Eq.4, negative currents) and the BOR (Eq.1, positive currents) (Figure 1).

$2 \mathrm{H}_{2} \mathrm{O}+2 \mathrm{e}^{-} \rightarrow \mathrm{H}_{2}+2 \mathrm{OH}^{-}$

The heterogeneous hydrolysis of $\mathrm{BH}_{4}{ }^{-}$(Eq.5) catalyzed by $\mathrm{Pt}, \mathrm{Pd}$ and $\mathrm{Ni}$ can be seen as a sum of the cathodic HER (Eq.4) and the anodic BOR (Eq.1):

$$
\mathrm{BH}_{4}^{-}+4 \mathrm{H}_{2} \mathrm{O} \rightarrow \mathrm{B}(\mathrm{OH})_{4}^{-}+4 \mathrm{H}_{2}
$$

Eq.4 and Eq.5 contribute (with other processes) to hydrogen generation during the BOR (Section 2.2).

\subsection{Hydrogen generation during the BOR}

Hydrogen generation during the BOR is evaluated in half-cell and in full DBFC by in situ DEMS measurements, or using a PEMFC module at the DBFC outlet, respectively. While Eq.4 accounts for hydrogen generation (from water) below $0 \mathrm{~V} v s \mathrm{RHE}, \mathrm{H}_{2}$ is also detected at positive potentials and high current densities. DEMS studies using deuterated fuel [22] on Pt and $\mathrm{Au}$ show that high-potential $\mathrm{H}_{2}$ is generated from $\mathrm{BD}_{4}^{-}$when the electrode surface is poisoned either by surface oxides (at high anodic potentials, Figure 1E) or by $\mathrm{BH}_{x}$ intermediates (at high borohydride concentration and/or low ECSA) [10]. High-potential $\mathrm{H}_{2}$ generation on $\mathrm{Pt}$ and $\mathrm{Au}$ may follow the occurrence of some dissociation steps involving $\mathrm{BH}_{4}^{-}$or reaction intermediates, e.g. $\mathrm{BH}_{\mathrm{x}, \mathrm{ad}}$ (Section 2.4). Figure $1 \mathrm{~F}$ represents the hydrogen escape rate versus current density in DBFC configuration: $\mathrm{H}_{2}$ formation during the BOR results in decreased faradaic efficiency and number-of-transferred-electrons per $\mathrm{BH}_{4}{ }^{-}$species from theoretical 8 down to 6 or even $2 \mathrm{e}^{-}$ , depending on the catalyst and applied conditions $\left(\mathrm{BH}_{4}^{-}\right.$concentration, potential, temperature, ECSA, surface coverage, etc.). While on $\mathrm{Pt}$ and $\mathrm{Au}$ the maximum number-of-transferredelectrons, approaches 8 under favorable conditions (Figure 1E), it does not exceed 4 on metallic 
$\mathrm{Ni}$ [23], probably because of its low HOR activity. Besides its impact on the faradaic efficiency, the released hydrogen may cause some problems during DBFC operation.

\subsection{Influence of the concentration of borohydride}

Figure 2 shows how the $\mathrm{BH}_{4}{ }^{-}$concentration affects the BOR kinetics on bulk $\mathrm{Pt}, \mathrm{Pd}, \mathrm{Au}$ and $\mathrm{Ni}$ surfaces measured in $\mathrm{RDE}$ configuration: increased $\mathrm{BH}_{4}{ }^{-}$concentration negatively shifts the OCP, because the BOR kinetics increases compared to the HER (Figure 2A). The lowest OCP values are observed for the metallic Ni electrode, because of its very low HER activity. However, increased $\mathrm{BH}_{4}^{-}$concentration also favors larger surface-poisoning by stronglyadsorbed intermediate $\mathrm{BH}_{\mathrm{x}, \mathrm{ad}}$ species, which depend on the ratio between the $\mathrm{BH}_{4}{ }^{-}$species concentration in the electrolyte and the number of available surface sites (ECSA) for the $\mathrm{BH}_{4}^{-}$ adsorption and reaction on the electrode. Figure $2 \mathrm{~B}$ shows the influence of the $\mathrm{BH}_{4}^{-}$ concentration on the $\mathrm{BOR}$ on $\mathrm{Pt}, \mathrm{Au}$ and $\mathrm{Pd}$ : the drastic poisoning of the Pt electrode surface manifests itself in $c a .0 .5 \mathrm{~V}$ shift of the BOR current wave towards positive potentials, resulting from the electrode surface blocking by strongly-adsorbed intermediate $\mathrm{BH}_{\mathrm{x}, \mathrm{ad}}$ species [24]. The effect is less pronounced for Pd and, especially, for Au electrodes (Figure 2B). An appropriate ratio between the concentration of $\mathrm{OH}^{-}$and $\mathrm{BH}_{4}^{-}$should also be maintained to achieve high BOR faradaic efficiency. According to Eq.1, this ratio should exceed 8, otherwise, problems related to local $\mathrm{pH}$ decrease in the vicinity of the electrode surface may appear [23], facilitating undesirable $\mathrm{BH}_{4}^{-}$hydrolysis [3].

Stable BOR activity is also mandatory for practical applications. Close to $0 \mathrm{~V} v s$ RHE, noble metals suffer from severe surface poisoning, resulting in prompt decay of the BOR activity at $0.2 \mathrm{~V} v s \mathrm{RHE}(\mathrm{Pt} / \mathrm{C}$ and $\mathrm{Pd} / \mathrm{C}$, Figure $2 \mathrm{C})$, which is accelerated with increased $\mathrm{BH}_{4}^{-}$ concentration from 5 to $50 \mathrm{mmol} \mathrm{L}^{-12}$. In opposition, metallic Ni/C yields relatively stable BOR activity, revealing the absence of strong poisoning under relevant BOR operation: the affinity of $\mathrm{Ni}$ to oxygen species (like $\mathrm{OH}^{-}$) at relatively low potentials facilitates complete oxidation of the BOR intermediates, as revealed by in situ FTIR measurements [23].

2 The poisoning effect resulting in the current decay in Fig 2C may be accelerated by the presence of impurities in the electrolyte, especially at high $\mathrm{NaBH}_{4}$ concentration. 

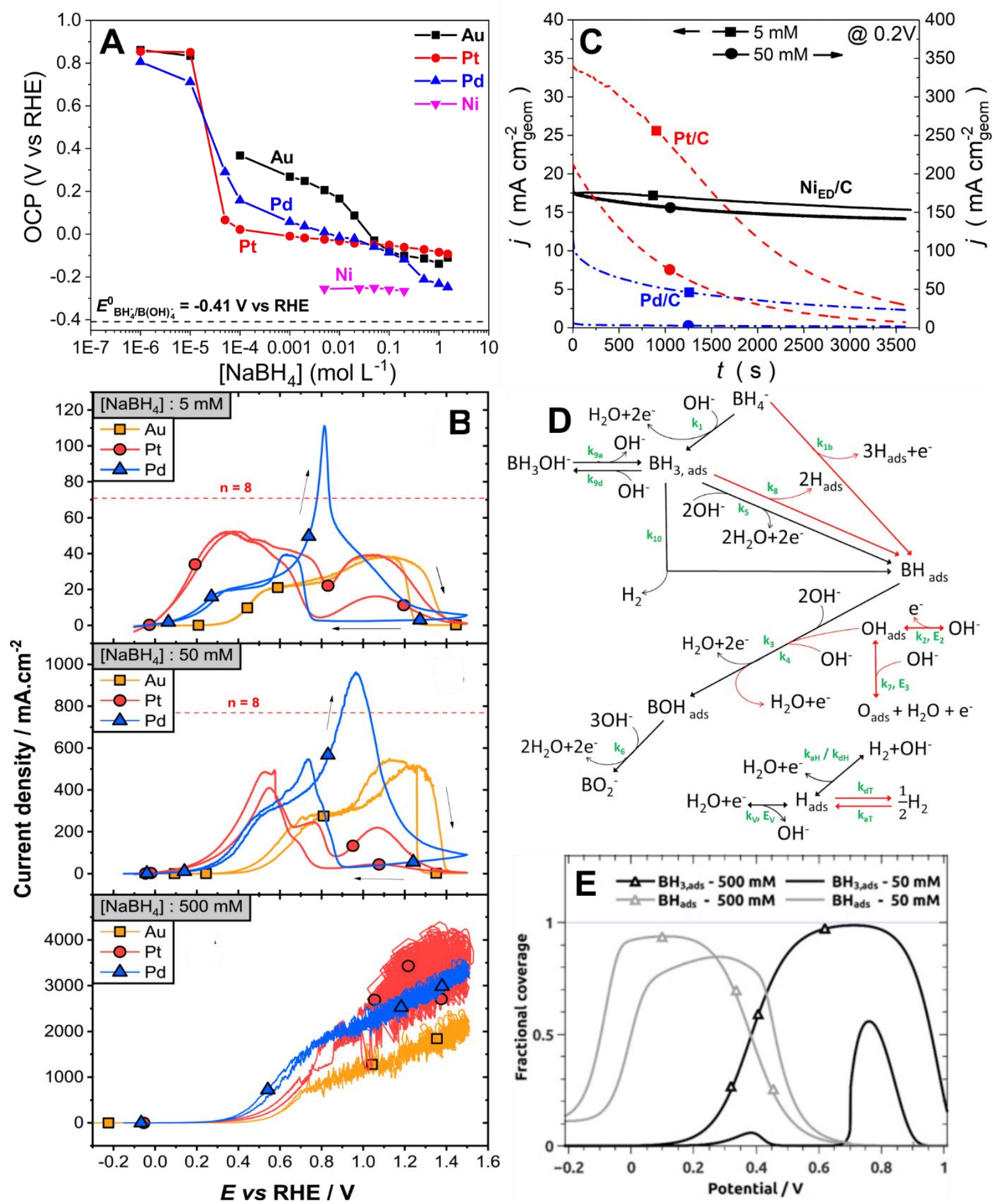

Figure 2. (A) OCP measured on polycrystalline $\mathrm{Au}, \mathrm{Pt}, \mathrm{Pd}$ and $\mathrm{Ni}$ electrodes for different concentrations of $\mathrm{NaBH}_{4}$ in $1 \mathrm{~mol} \mathrm{~L}^{-1} \mathrm{NaOH}$ at $T=20^{\circ} \mathrm{C}$ and $\omega=1600 \mathrm{rpm}$. (B) Ohmic dropcorrected (in dynamic mode) CVs of BOR ( $v=20 \mathrm{mV} \mathrm{s}^{-1}, \omega=2500 \mathrm{rpm}, T=20^{\circ} \mathrm{C}$ ) on polycrystalline $\mathrm{Au}, \mathrm{Pt}$ and $\mathrm{Pd}$ electrodes at different concentration of $\mathrm{NaBH}_{4}$; replotted from [24] with permission from Elsiever. (C) Potentiostatic measurement of the BOR on metallic $\mathrm{Ni}_{\mathrm{ED}} / \mathrm{C}$ ( solid curve), $\mathrm{Pt} / \mathrm{C}$ (dashed curve), $\mathrm{Pd} / \mathrm{C}$ (dash-dotted curve) in $\mathrm{N}_{2}$-saturated $1.0 \mathrm{~mol} \mathrm{~L}$ ${ }^{1} \mathrm{NaOH}+5$ or $50 \mathrm{mmol} \mathrm{L}^{-1} \mathrm{NaBH}_{4}$ at $E=0.2 \mathrm{~V}$ vs RHE and $\omega=1600 \mathrm{rpm}$; reproduced from 
[9] with permission from the American Chemical Society; (D) Tentative BOR mechanism on $\mathrm{Pt}$ and $\mathrm{Au}$. Red-colored arrows correspond to the steps occurring on Pt only [10]. (E) $\mathrm{BH}_{3, \mathrm{ads}}$ and $\mathrm{BH}_{\mathrm{ads}}$ surface coverage simulated for $\mathrm{BOR}$ on a $\mathrm{Pt}$ electrode at different $\mathrm{BH}_{4}^{-}$ concentrations within the model shown in panel (D); reproduced from [10] with permission from Elsevier.

\subsection{BOR mechanism}

BOR mechanism determination was achieved for various anode materials using electrochemical (e.g. rotating ring-disc voltammetry), spectroscopic (DEMS, in situ infrared spectroscopy) and computational methods (density functional theory, DFT, and microkinetic modeling). The difference in the BOR activity of $\mathrm{Pt}, \mathrm{Pd}, \mathrm{Au}$ and $\mathrm{Ni}$ can be explained considering the binding energies of the key intermediate species: $\mathrm{H}_{\mathrm{ad}}, \mathrm{BH}_{4, \mathrm{ad}}$ and $\mathrm{BH}_{\mathrm{ad}}$, on these metals, which have been calculated by DFT (Table 1). On Pt, $\mathrm{BH}_{4}^{-}$adsorbs dissociatively, forming strongly-adsorbed $\mathrm{BH}_{\mathrm{ad}}$ and $\mathrm{H}_{\mathrm{ad}}$. The latter species are easily oxidized on Pt above $0 \mathrm{~V}$ vs $\mathrm{RHE}$ (contributing to the currents), but escape as $\mathrm{H}_{2}$ below $0 \mathrm{~V} v s$ RHE (hence $\mathrm{H}_{2}$ detection in DEMS). To account for the 'high-potential' $\mathrm{H}_{2}$ escape, an incomplete $\mathrm{BH}_{4}{ }^{-}$dissociation into $\mathrm{BH}_{3, \text { ads }}$, was proposed, the latter occurring on $\mathrm{Pt}$ 'poisoned' either by surface oxides or by $\mathrm{BH}_{x}$ intermediates (Figure 2D). Figure 2E shows $\mathrm{Pt}$ surface-coverage with $\mathrm{BH}_{3, \text { ads }}$ and $\mathrm{BH}_{\mathrm{ads}}$ intermediates at different borohydride concentrations. $\mathrm{BH}_{3, \text { ads }}$ can desorb from the "poisoned" Pt surface to form $\mathrm{BH}_{3} \mathrm{OH}^{-}$, which can be detected using a RRDE. In contrast, the low $\mathrm{BH}_{4, \text { ads }}$ binding-energy on $\mathrm{Au}$ surface results in slow BOR kinetics around $0 \mathrm{~V}$ vs RHE, requiring significant overpotential ( $c a .0 .7 \mathrm{~V}$ ) to initiate the reaction. The weak $\mathrm{BH}_{4}^{-}$adsorption on $\mathrm{Au}$ leads to incomplete $\mathrm{BH}_{4}{ }^{-}$dissociation into $\mathrm{BH}_{3, \text { ad }}$, accompanied with larger $\mathrm{H}_{2}$ escape in a wider potential interval but smaller surface-poisoning by strongly-adsorbed intermediates.

According to DFT calculations, $\mathrm{BH}_{4, \text { ad }}$ binding is intermediate on $\mathrm{Ni}(111)$ versus $\mathrm{Au}$ and $\mathrm{Pt}$. The reaction path follows initial $\mathrm{B}-\mathrm{H}$ dissociation followed by $\mathrm{BH}_{3}-\mathrm{OH}$ bond formation, successive $\mathrm{B}-\mathrm{H}$ dissociation into $\mathrm{BOH}_{\mathrm{ad}}$, and then final $\mathrm{B}(\mathrm{OH})_{3}$ product formation [23]. On Ni surfaces covered by $\mathrm{H}_{\mathrm{ad}}$ and $\mathrm{BH}_{\mathrm{x}, \mathrm{ad}}$ species, the $\mathrm{B}-\mathrm{H}$ dissociation will be hindered, affecting the reaction mechanism. $\mathrm{BH}_{4}{ }^{-}$adsorption on $\mathrm{Ni}$ is strong-enough to allow fast adsorption but nottoo-strong to favor severe surface poisoning (typical for $\mathrm{Pt}$ ). $\mathrm{H}_{\mathrm{ad}}$ is more strongly adsorbed on metallic $\mathrm{Ni}$ than on $\mathrm{Pt}$, resulting in slower $\mathrm{H}_{\mathrm{ad}}$ oxidation and slow rate of competing HER, which is the key to achieve low BOR onset potential. The downside of $\mathrm{Ni}$ is its inability to valorize 8 
$\mathrm{e}^{-}$'stored' in the $\mathrm{BH}_{4}^{-}$fuel: $\mathrm{BOR}$ on $\mathrm{Ni}$ rather occurs in a $4 \mathrm{e}^{-}$process, producing $2 \mathrm{H}_{2}$ per $\mathrm{BH}_{4}{ }^{-}$ , the exact BOR mechanism on Ni being not fully understood, yet.

According to DFT calculations, $\mathrm{Pd}(111)$ should also catalyze the $\mathrm{BH}_{4}^{-}$dissociativeadsorption. However, the experimental current-potential curves are strongly affected by Pd hydrides formation, making mechanistic elucidation more difficult.

Table 1. DFT-calculated adsorption energies for selected adsorbates on $\mathrm{Ni}(111), \mathrm{Pt}(111)$, $\mathrm{Au}(111)$ and $\mathrm{Pd}(111)$ at zero coverage limit

\begin{tabular}{ccccc}
\multirow{2}{*}{ Species } & \multicolumn{4}{c}{ Binding energy (eV) } \\
& $\mathrm{Ni}(111)$ & $\mathrm{Pt}(111)$ & $\mathrm{Pd}(111)$ & $\mathrm{Au}(111)$ \\
\hline \multirow{2}{*}{$\mathrm{BH}_{4} *$} & $-3.68[9]$ & - & - & $-1.73[26]$ \\
& $-3.50[25]$ & $-4.73[27]$ & $-3.63[25]$ & $-1.96[25]$ \\
$\mathrm{BH}+3 \mathrm{H}^{*}$ & - & $-4.56[25]$ & - & $-0.55[26]$ \\
$\mathrm{BH}_{3} *$ & -2.19 & $-1.94[27]$ & - & $-2.04[28]$ \\
$\mathrm{H}^{*}$ & $-2.81[28]$ & $-2.70[28]$ & $-2.83[28]$ & $-2.18[29]$ \\
$\mathrm{OH}^{*}$ & $-2.94[29]$ & $-2.72[29]$ & $-2.88[29]$ & $-1.56[28]$ \\
\hline
\end{tabular}

\section{Several types of separator/membranes for the DBFC}

This section briefly compares various types of DBFC separators focusing on the advantages and drawbacks of either choice rather than a comprehensive analysis of currently existing materials.

\subsection{Cation Exchange membranes (CEM)}

CEM, the most advanced on an industrial/commercial viewpoint, possess numerous advantages: high chemical stability, mechanical properties and commercial availability. In theory, CEMs exhibit reduced fuel cross-over (Donnan exclusion of $\mathrm{BH}_{4}^{-}$anion from $\mathrm{SO}_{3}{ }^{-}$ groups), but cannot suppress it, which can compromise the cathode performance if its catalyst is not $\mathrm{BH}_{4}{ }^{-}$-tolerant (Section 4) [30]. In a DBFC, a CEM operates in $\mathrm{Na}^{+}$form (for $\mathrm{NaOH}$-based anolytes), which compromises the cell Ohmic-drop, owing to the low conductivity of $\mathrm{Na}^{+}-$ CEMs versus $\mathrm{H}^{+}-\mathrm{CEM}$. Besides, this enables $\mathrm{NaOH}$ displacement towards the cathode side, where (for $\mathrm{O}_{2}$-fed DBFCs) it tends to precipitate, leading to reduced $\mathrm{O}_{2}$ mass-transport efficiency to the cathode sites [31] (Figure 3A), hence depreciating the cathode and DBFC 
performance. For $\mathrm{H}_{2} \mathrm{O}_{2}$-DBFCs, CEMs lead to intense proton migration/diffusion from the (acidic) catholyte side to the anode side [32], promoting severe $\mathrm{BH}_{4}^{-}$hydrolysis and depreciated performance (the cell anode then behaves like in a standard hydrogen fuel cell) [33].
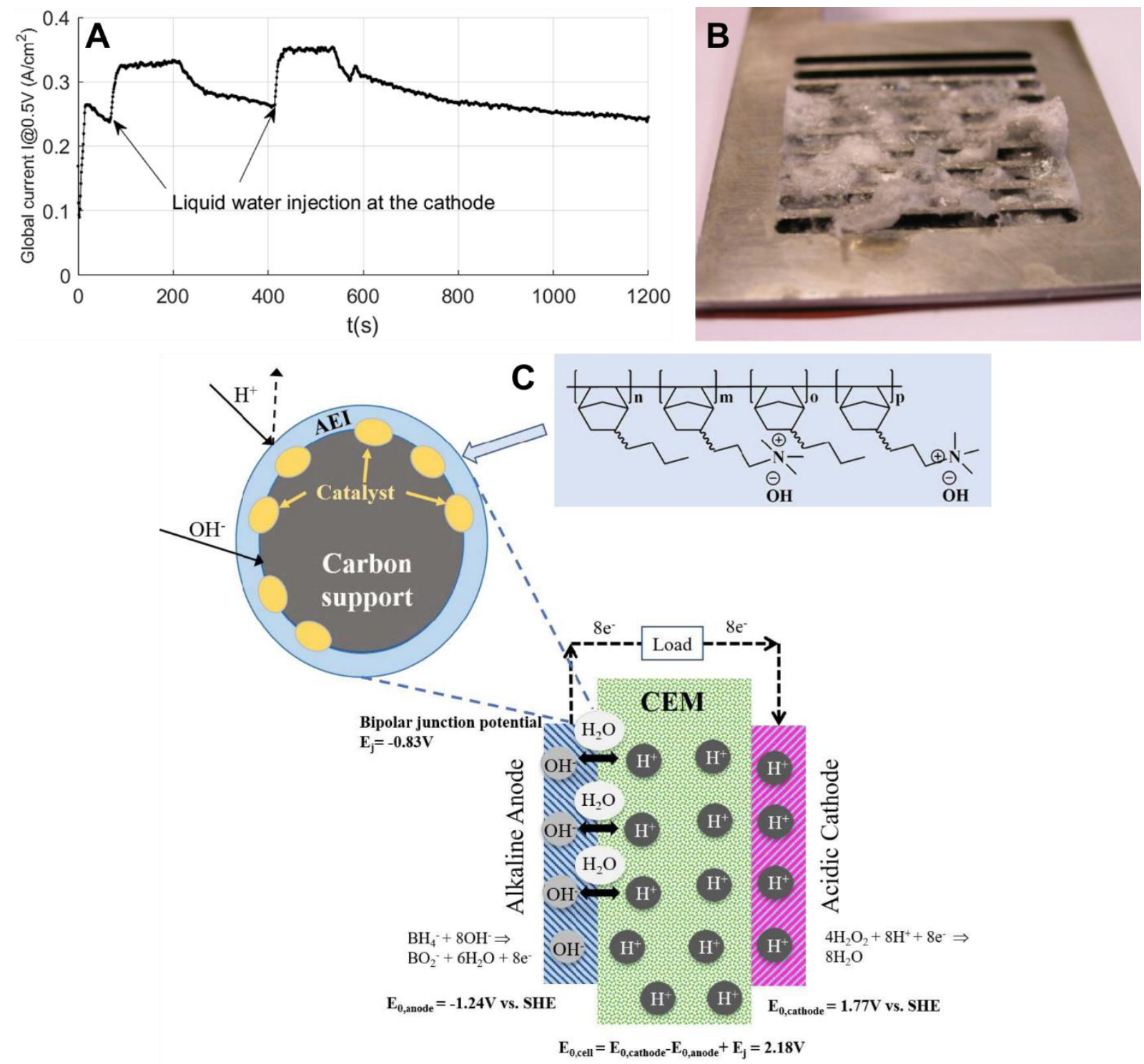

Figure 3: (A) Injection of liquid water at the cathode enables transient recovery of the performance during operation of a CEM-based DBFC at $U_{\text {cell }}=0.5 \mathrm{~V}, T=60^{\circ} \mathrm{C}$ with a Pt/C cathode, because it washes the accumulated $\mathrm{NaOH}$; reproduced from [31] with permission from Elsevier. (B) When the DBFC is operated with an anion-exchange membrane, the fuel $\left(\mathrm{NaBH}_{4}\right)$ and its oxidation products $\left(\mathrm{NaBO}_{2}\right)$ can be deposited in the channels of the cathode bipolar plate; reproduced from [20] with permission from Elsevier. (C) Illustration of the way a $\mathrm{H}_{2} \mathrm{O}_{2-}$ DBFC operates with $\mathrm{pH}$-gradient-enabled microscale bipolar interface (BPM). Reproduced from [34] with permission from the American Chemical Society. 


\subsection{Anion-Exchange membranes (AEM)}

AEM should prevent such $\mathrm{NaOH}$ (DBFCs) or $\mathrm{H}^{+}\left(\mathrm{H}_{2} \mathrm{O}_{2}\right.$-DBFCs) displacement. AEM enabled the best-reported performance for DBFCs: $810 \mathrm{~mW} \mathrm{~cm}^{-2}$, for a $5 \mathrm{~cm}^{2}$ cell operated at $70^{\circ} \mathrm{C}$, with a Pd+Ni-based anode (5 wt.\% $\mathrm{NaBH}_{4}$ in $10 \mathrm{wt} . \% \mathrm{NaOH}$ anolyte) and a $\mathrm{Pt} / \mathrm{C}$ cathode $\left(\mathrm{O}_{2}\right)$ [35]. Many home-made (and then commercial) AEM were then tested in DBFC; their main drawback is associated to the unavoidable $\mathrm{BH}_{4}^{-}$(fuel) and $\mathrm{BO}_{2}^{-}$(final product) anion crossover they generate [20], which leads to the re-precipitation of these compounds in the cathode and in its bipolar plate channels (Figure 3B). The corresponding non-negligible presence of fuel at the cathode renders mandatory the use of either $\mathrm{BH}_{4}{ }^{-}$-tolerant $\mathrm{ORR}$ catalysts or complex balance-of-plant to avoid detrimental mixed potential at the cathode and reach high performance. It is wise to say that non-noble cathode materials have assets in terms of fuel tolerance, and that they have a chance to be stable when used at the interface of an AEM, thus allowing DBFC to operate without noble metal catalysts (Section 4).

\subsection{Bipolar membranes (BPM)}

BPMs, combining a CEM side and an AEM side, are relevant for liquid-liquid DBFCs $\left(\mathrm{H}_{2} \mathrm{O}_{2}\right.$ DBFCs), where they enable to maintain the required $\mathrm{pH}$-gradient between the alkaline $\mathrm{BH}_{4}^{-}$ anolyte and acidic $\mathrm{H}_{2} \mathrm{O}_{2}$ catholyte [33, 36] (Figure 3C). Proper BPM operation requires that water-splitting easily occurs at the CEM|AEM interface, which implies an unavoidable junction potential [36]; the $\mathrm{OH}^{-}$and $\mathrm{H}^{+}$produced then travel to the anode and cathode sides of the cell, respectively, to participate in the BOR and HPRR. BPM can lead to high-performance $\mathrm{H}_{2} \mathrm{O}_{2}$ DBFC [33], but involve non-negligible consumption of base from the anolyte and acid from the catholyte, which limits the cell practical energy-density [36]. The interest of BPM has not yet been demonstrated for classical $\left(\mathrm{O}_{2}\right.$-fed) DBFCs.

\subsection{Porous separators (or membraneless cells)}

Membraneless DBFCs were reported, either in conventional DBFC operation with a cobaltbased anode and $\mathrm{LaNiO}_{3}$ (or $\mathrm{MnO}_{2}$ ) fuel-tolerant cathodes [37, 38], or with a ceriumammonium-nitrate reduction at the cathode [39]. This latter strategy is poorly compatible with high cell performance and easy operation, owing to complex fuel/oxidant management when 
the anode and cathode are not really separated. Porous separators have nevertheless been successfully employed in "Swiss-roll” mixed reactant cells, in which (in-principle) fuel-tolerant ORR catalyst (e.g. $\mathrm{MnO}_{2}$ ) and oxidant-tolerant BOR catalyst must be used [40]. With proper management of the fuel/oxidant flows and cell/electrode/separator geometry, non-tolerant catalysts can however be used without detrimental performance losses [41].

\section{The cathode reaction in a DBFC}

As specified in the Introduction, DBFC can operate with either ORR or HPRR at the cathode. This Section briefly discusses how the choice of the cathode reaction affects DBFC performance and the criteria imposed on the cathode electrocatalysts.

\subsection{Oxygen reduction reaction}

The ORR (Eq.2) is the usual cathode reaction in a DBFC, $\mathrm{O}_{2}$ being advantageouslyharvested from air at no cost. Because of the alkaline anolyte and the imperfect separation brought by the membrane/separator, alkaline ORR is at stake in a DBFC; Pt and Ag-based catalysts are very active for this reaction, but are not $\mathrm{BH}_{4}^{-}$tolerant/selective [42]. So, they shall not be used with an AEM, that leads to consequent fuel crossover (see section 3.2). Many Aubased or Ag-based alloys were mentioned for ORR in DBFCs, but the materials are also active for the BOR, a real non-sense (see e.g. [43-45]). With a CEM, such noble catalyst can be used, even if for alkaline fuel cells like the DBFC, one rather envisions to use non-noble catalysts also at the cathode.

Non-noble catalysts are usually less active than Pt and Ag for "pure ORR" but more tolerant/selective in presence of a fuel. The literature is extremely rich in studies of non-Pt ORR catalysts, and several have been successfully demonstrated in AEM-based or separator-based DBFCs. Without being exhaustive, one can cite Fe-N-C or Co-N-C [46], $\mathrm{MnO}_{2}$ [42, 47], $\mathrm{LaNiO}_{3}[37,38]$. 


\subsection{Hydrogen peroxide reduction reaction (HPRR)}

The HPRR usually occurs in acidic conditions in $\mathrm{H}_{2} \mathrm{O}_{2}$-DBFCs, $\mathrm{H}_{2} \mathrm{O}_{2}$ being less stable in base. Using the HPRR is advantageous in some applications where gaseous reactant are dangerous, e.g. submarines [33, 48]. Acid-stable Au or Au-based catalysts [33] and Pt/C [48] are the norm, and more complex chemistries of catalysts were also evaluated, like Pt-rare Earths (quite active) [49] and perovskites (poorly-performing) [50]. Proper engineering the cathode catalyst layer and balance-of-plant of the $\mathrm{H}_{2} \mathrm{O}_{2}$-DBFC is critical to achieve good $\mathrm{H}_{2} \mathrm{O}_{2}$-DBFC performance [32].

\section{Performance, stability and durability in DBFC operation}

\subsection{Effect of the electrodes/diffusion medium structure}

The previous sections made clear that the core materials of $\left(\mathrm{H}_{2} \mathrm{O}_{2^{-}}\right)$DBFCs drive their performance; their assembly, interface and structure also have a dramatic impact, in particular for the anode: (i) cracked (porous) layers (Figure 4A, B) (ii) graded layers based on $\mathrm{Pd} / \mathrm{C}$ and $\mathrm{Pt} / \mathrm{C}$ catalysts (Figure 4C) [48] all enabled to optimize the (very complex) mass-transport processes in DBFC anodes. 

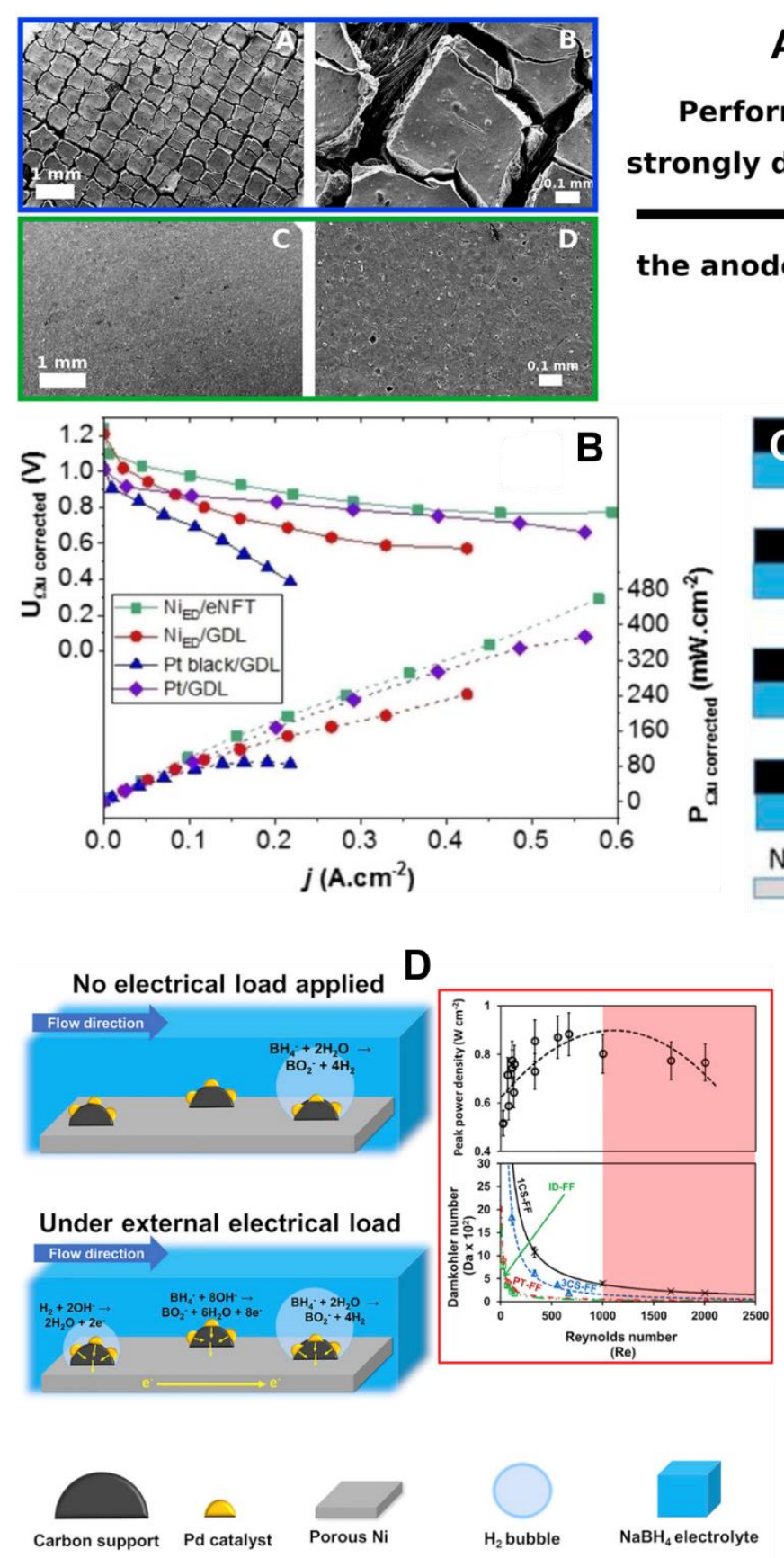

A
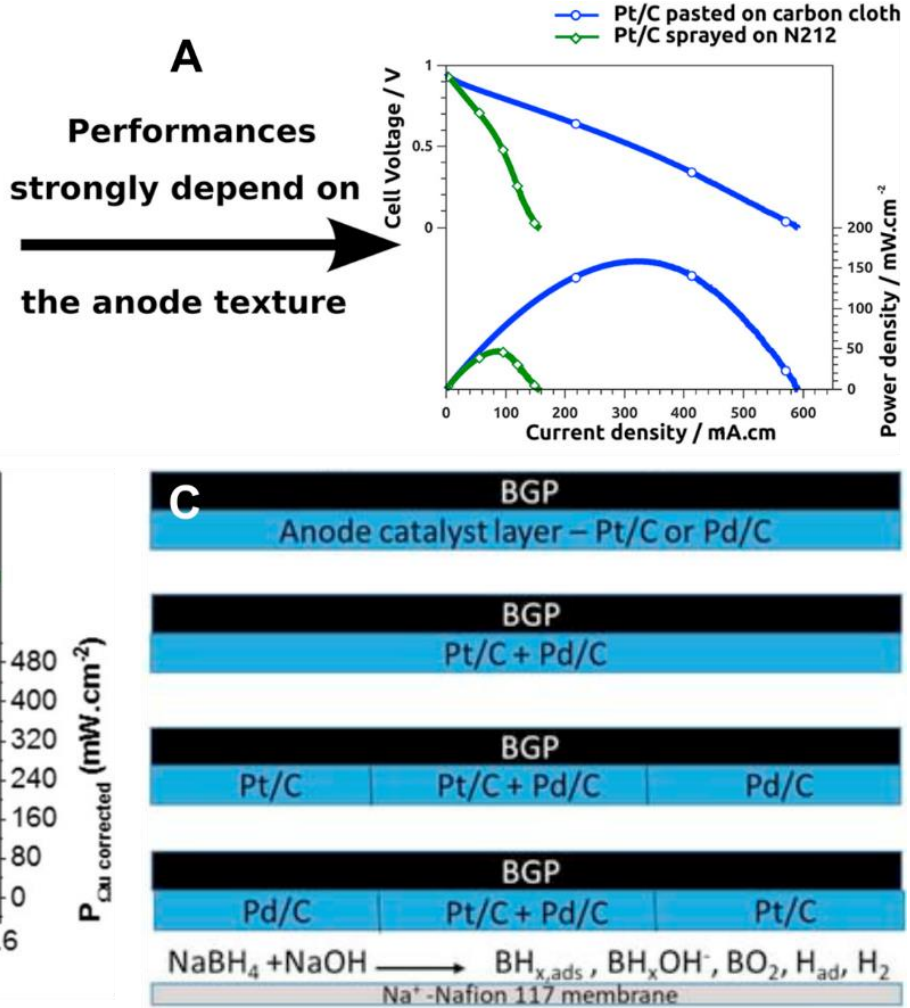

$\mathbf{E}$

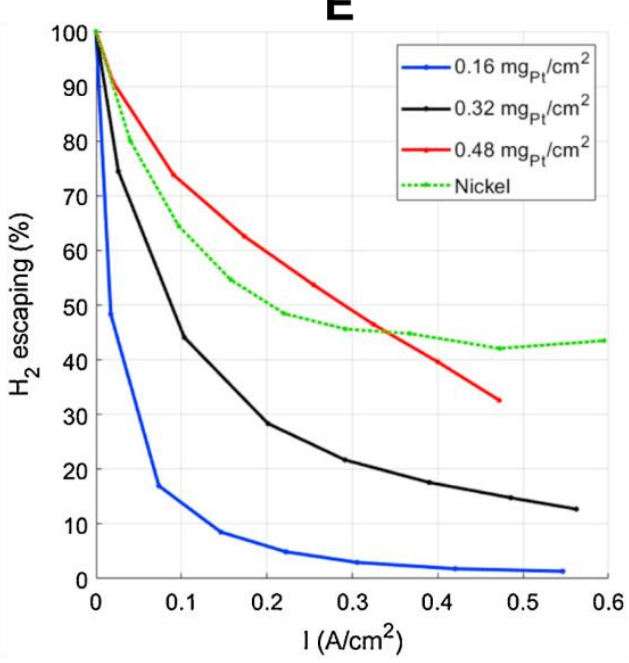

Figure 4: (A) Illustration of the impact of the performance of a DBFC depending on the morphology of the Pt/C-based anode active layer, all other parameters being kept identical; open macropores enable better management of the mass-transport of the liquid fuel and generated $\mathrm{H}_{2}$ bubbles; reproduced from [51] with permission from Elsevier. (B) Similar effect were observed for Ni-based anodes; reproduced from [52] with permission from Wiley-VCH Verlag $\mathrm{GmbH}$. (C) Graded electrodes made of $\mathrm{Pt} / \mathrm{C}$ and $\mathrm{Pd} / \mathrm{C}$ were prepared for optimized $\mathrm{H}_{2} \mathrm{O}_{2}$-fed DBFC operation; reproduced from [48] with permission from The Electrochemical Society. (D) Illustration of reactant-transport engineering to mitigate parasitic reactions (HER, $\mathrm{BH}_{4}{ }^{-}$hydrolysis) to the BOR and improve the performance of liquid-fed DBFCs; reproduced 
from [53] with permission from CellPress. (E) Adapting the Pt nanoparticles density (catalyst loading) at the surface of carbon-fiber anodes enables to control the rate of $\mathrm{H}_{2}$ escape during the BOR in DBFC; reproduced from [54] with permission from Elsevier.

Indeed, the BOR completion and kinetics strongly depends on the mass-transport of $\mathrm{BH}_{4}{ }^{-} / \mathrm{OH}^{-} / \mathrm{H}_{2}$ to/from the catalytic sites within the porous texture of the electrode $[52,55,56]$. So, the diffusion layer upstream the anode has a marked influence on the anode performance, thin/open layers being beneficial to $\mathrm{H}_{2}$-bubbles evacuation and liquid anolyte access [21]. The concept can be extended to the channels feeding the anolyte solution in a $\mathrm{H}_{2} \mathrm{O}_{2}$-DBFC: engineering the reactant-transport within the anode flow field architecture and fuel flowrates mitigates parasitic borohydride hydrolysis and hydrogen oxidation reactions, and minimizes anode masking by hydrogen bubbles [53] (Figure 4D).

\subsection{Stability of DBFC performance and durability of DBFC catalysts}

Although DBFCs are still at their infancy compared to PEMFCs, some studies have evaluated their stability in operation. For example, the start/stop operation of a (CEM-based) DBFC was studied [31]: using a ORR-inactive anode catalyst can prevent cell reversal issues that are often encountered in PEMFC.

From a materials view-point, operation in the high-pH environment of the anode is very detrimental to carbon-supported electrocatalysts [51, 57, 58]. Anode catalyst erosion from their substrate is often mentioned as one cause of DBFC instability [59]; cathode catalyst dissolution and re-deposition at the anode, and detachment of carbon-supported nanoparticles after DBFC operation are additional explanation for the instability of PGM-based DBFCs upon prolonged operation [51]. Non-PGM Co-Ni-B [60] and NiB [61] BOR anode catalyst were found rather active/stable in prolonged DBFC operation.

CEM stability in DBFCs is never reported as a major issue; however, the temperature strongly influences their performance in DBFC, because of a complex interplay between imperfect anode/cathode separation (and related mixed potentials), high sensitivity of $\mathrm{Na}^{+}$-ionic conductivity to temperature, $\mathrm{BH}_{4}^{-}$-hydrolysis, and usual electrokinetic/mass-transport effects $[4,31,51]$.

There is no data reporting AEM-based stability in DBFC operation; if their hydration is properly-controlled (which is easier for DBFCs fed with a liquid-based anolyte), AEM can be fairly stable on the long-term, though, especially with $\mathrm{CO}_{2}$-scrubbed incoming air [62, 63]. 
BPM did show 50 h-long performance-stability upon $\mathrm{H}_{2} \mathrm{O}_{2}$-DBFC operation [33], and porous BPM ca. 300 h-long operation at $200 \mathrm{~mA} \mathrm{~cm}^{-2}$ [64].

One clear difference between DBFCs and their $\mathrm{H}_{2}$-fed counterparts is the formation of $\mathrm{H}_{2}$ from the HER (when the anode operates below $0 \mathrm{~V} v s$ RHE - as desired) or from catalytic decomposition of $\mathrm{BH}_{4}^{-}$; this $\mathrm{H}_{2}$ must be valorized as much as possible if formed (which $\mathrm{Pt}$ does above $0 \mathrm{~V} v s \mathrm{RHE}$ ), but ideally not produced. Metallic $\mathrm{Ni}$ is an interesting catalyst in that extent, because it enables to lower the low-potential $\mathrm{H}_{2}$ production, hence enabling higher voltage DBFC operation than $\mathrm{Pt}$ (Figure 4B), but is incapable to valorize the $\mathrm{H}_{2}$ it produces, leading to non-negligible $\mathrm{H}_{2}$-escape (Figure $4 \mathrm{E}$ ). To manage properly $\mathrm{H}_{2}$ production and escape, materials strategy are advantageously complemented by engineering ones [34, 52, 53, 65]. 


\section{Concluding remarks}

DBFCs are very versatile systems, which offer many possibilities in terms of usable core materials (at the anode, cathode, for the separator/membrane), fuel (liquid anolyte, whose $\mathrm{pH}$ and $\mathrm{BH}_{4}{ }^{-}$concentration can be varied) and oxidant (gaseous $\mathrm{O}_{2}$, acidic $\mathrm{H}_{2} \mathrm{O}_{2}$ catholyte). Their performances are tightly linked not only to their core materials, but also to their assembly and structure: the core materials must be selected according to the operating conditions and electrode/cell structures chosen. This stimulates intense research efforts, that recently led to spectacular fundamental understanding and technical performances.

This selected review highlighted that, although many anode catalysts have been studied since the pioneering work of Amendola 20 years ago, by now, significant progress in the understanding of the complex BOR mechanism has only been achieved for rather simple catalysts (monometallic Pt-, Pd-, Au- and Ni-based). Among them, only Pt and Ni present sufficient extent of low-potential activity, though for different reasons. While Pt dissociatively adsorbs $\mathrm{BH}_{4}-$ into $\mathrm{BH}_{\mathrm{ad}}$ and $\mathrm{H}_{\mathrm{ad}}$ and then near-completely oxidizes $\mathrm{H}_{\mathrm{ad}}$ (only above $0 \mathrm{~V}$ vs $\mathrm{RHE}$ but at a very fast rate, hence leading to faradaic efficiency close to $100 \%$ on properly-designed electrodes), $\mathrm{Ni}$ in its metal state is capable to catalyze anodic $\mathrm{BH}_{4}{ }^{-}$oxidation without promoting the unwanted cathodic HER, hence leading to non-negligible BOR currents at potential below $0 \mathrm{~V}$ vs RHE. However, the BOR mechanism on Ni involves generation of significant amount of $\mathrm{H}_{2}$ that the electrode is incapable to properly oxidize; this results in non-negligible $\mathrm{H}_{2}$-escape. In addition, the mechanisms of the BOR and its competing reactions are strongly influenced by the operating conditions of the anode. The nature of the membrane/separator has a marked influence on the DBFC performance. The choice of the membrane/separator not only defines the ionic conductivity but also affects crossover of the anolyte species $\left(\mathrm{Na}^{+}\right.$for a cationexchange membrane and anionic fuel species for an anion-exchange membrane). Because of this, AEMs must be employed in conjunction with a fuel-tolerant cathode catalyst (usually nonnoble). In addition, the structure and the texture of the anode is pivotal to its proper performance, so to enable optimized mass-transport for the fuel and its numerous (desired or not) reaction products. Finally, like any other fuel cells, DBFCs are subjected to degradation issues, and these are very specific to their fuel (liquid alkaline anolyte); while PGM-based catalysts are very sensitive to these degradations, non-PGM ones (e.g. Ni-based) seem more stable, another asset of these materials for DBFC operation.

\section{Acknowledgments}


This work was supported by the National Research Agency, in the frame of the MobiDiC project (ANR-1-CE05-0017). Some of the work presented herein has been performed within the framework of the Centre of Excellence of Multifunctional Architectured Materials "CEMAM" No. ANR-10-LABX-44-01. A.O. acknowledges the support from the Ministry of Science and Higher Education of the Russian Federation within the governmental order for Boreskov lnstitute of Catalysis (project AAAA-A21-121011390006-0)

\section{Author contributions}

All authors have contributed equally.

\section{Lexicon}

AEM: Anion Exchange Membrane

BOR: Borohydride Oxidation Reaction

BPM: BiPolar Membrane

CEM: Cation Exchange Membrane

DBFC: Direct Borohydride Fuel Cell (using $\mathrm{O}_{2}$ as oxidant)

DEMS: Differential Electrochemical Mass Spectrometry

DFT: Density Functional Theory

FTIR: Fourier-Transform Infra-Red spectroscopy

$\mathrm{H}_{2} \mathrm{O}_{2}$-DBFC: Hydrogen Peroxide Direct Borohydride Fuel Cell (using $\mathrm{H}_{2} \mathrm{O}_{2}$ as oxidant)

HER: Hydrogen evolution Reaction

HOR: Hydrogen oxidation Reaction

HPRR: Hydrogen Peroxide Reduction Reaction

OCP: Open Circuit Potential

ORR: Oxygen Reduction Reaction

R(R)DE: Rotating (Ring) Disk electrode

\section{References and recommended reading}

Papers of particular interest, published within the period of review, have been highlighted as:

* Paper of special interest.

** $\quad$ Paper of outstanding interest. 
[1] S.C. Amendola, P. Onnerud, M.T. Kelly, P.J. Petillo, S.L. Sharp-Goldman, M. Binder, A novel high power density borohydride-air cell, J. Power Sources, 84 (1999) 130.

[2] M.E. Indig, R.N. Snyder, Sodium Borohydride, an Interesting Anodic Fuel .1, J. Electrochem. Soc., 109 (1962) 1104.

[3] K.N. Mochalov, V.S. Khain, G. Gilmansh, A generalized scheme for hydrolysis of borohydride ion and diborane, Doklady Akademii Nauk Sssr, 162 (1965) 613.

[4] P.-Y. Olu, N. Job, M. Chatenet, Evaluation of anode (electro)catalytic materials for the direct borohydride fuel cell: Methods and benchmarks, J. Power Sources, 327 (2016) 235.

* $\quad$ First paper that proposes methods and benchmarks to evaluate DBFC anode catalysts

[5] I. Merino-Jiménez, C. Ponce De León, A.A. Shah, F.C. Walsh, Developments in direct borohydride fuel cells and remaining challenges, J. Power Sources, 219 (2012) 339.

[6] P. Olu, A. Zadick, N. Job, M. Chatenet, Anode Electrocatalysts for Direct Borohydride and Direct Ammonia Borane Fuel Cells, in: Electrocatalysts for Low Temperature Fuel Cells: Fundamentals and Recent Trends, 2017, pp. 317-346.

[7] G. Rostamikia, M.J. Janik, Direct borohydride oxidation: mechanism determination and design of alloy catalysts guided by density functional theory, Energy Environ. Sci., 3 (2010) 1262 .

** Based on DFT calculations, this paper proposes guidances to design better BOR catalysts

[8] A.G. Oshchepkov, G. Braesch, A. Bonnefont, E.R. Savinova, M. Chatenet, Recent Advances in the Understanding of Nickel-Based Catalysts for the Oxidation of HydrogenContaining Fuels in Alkaline Media, ACS Catal., 10 (2020) 7043.

[9] A.G. Oshchepkov, G. Braesch, S. Ould-Amara, G. Rostamikia, G. Maranzana, A. Bonnefont, V. Papaefthimiou, M.J. Janik, M. Chatenet, E.R. Savinova, Nickel Metal Nanoparticles as Anode Electrocatalysts for Highly Efficient Direct Borohydride Fuel Cells, ACS Catal., 9 (2019) 8520.

** This paper shows that metallic Ni ouperforms any other catalyst for the BOR at low potential, an endeavor for DBFC applications. However, the state-of-surface of Ni must be tightly controlled, as oxidized $\mathrm{Ni}$ is far less efficient for the BOR

[10] P.-Y. Olu, A. Bonnefont, G. Braesch, V. Martin, E.R. Savinova, M. Chatenet, Influence of the concentration of borohydride towards hydrogen production and escape for borohydride oxidation reaction on $\mathrm{Pt}$ and Au electrodes - experimental and modelling insights, J. Power Sources, 375 (2018) 300.

* This paper demonstrates that the operating conditions strongly influence the BOR pathway and efficiency for Pt and Au electrodes

[11] M. Simões, S. Baranton, C. Coutanceau, C. Lamy, J.M. Léger, Proc. ECS Trans., 2009.

[12] L. Yi, W. Wei, C. Zhao, L. Tian, J. Liu, X. Wang, Enhanced activity of Au-Fe/C anodic electrocatalyst for direct borohydride-hydrogen peroxide fuel cell, J. Power Sources, 285 (2015) 325.

[13] X. Geng, H. Zhang, Y. Ma, H. Zhong, Borohydride electrochemical oxidation on carbonsupported Pt-modified Au nanoparticles, J. Power Sources, 195 (2010) 1583.

[14] A.M. Pasqualeti, P.-Y. Olu, M. Chatenet, F.H.B. Lima, Borohydride electrooxidation on carbon-supported noble metal nanoparticles: Insights into hydrogen and hydroxyborane formation, ACS Catal., 5 (2015) 2778.

[15] F.G. Boyaci San, O. Okur, T. Iyigün Karadağ, I. Isik-Gulsac, E. Okumuş, Evaluation of operating conditions on DBFC (direct borohydride fuel cell) performance with PtRu anode catalyst by response surface method, Energy, 71 (2014) 160.

[16] G.R. Li, Q.Q. Wang, B.H. Liu, Z.P. Li, Porous Carbon as Anode Catalyst Support to Improve Borohydride Utilization in a Direct Borohydride Fuel Cell, Fuel Cells, 15 (2015) 270. 
[17] Z.P. Li, B.H. Liu, J.K. Zhu, S. Suda, Depression of hydrogen evolution during operation of a direct borohydride fuel cell, J. Power Sources, 163 (2006) 555.

[18] X. Geng, H. Zhang, W. Ye, Y. Ma, H. Zhong, Ni-Pt/C as anode electrocatalyst for a direct borohydride fuel cell, J. Power Sources, 185 (2008) 627.

[19] R. Jamard, A. Latour, J. Salomon, P. Capron, A. Martinent-Beaumont, Study of fuel efficiency in a direct borohydride fuel cell, J. Power Sources, 176 (2008) 287.

[20] R. Jamard, J. Salomon, A. Martinent-Beaumont, C. Coutanceau, Life time test in direct borohydride fuel cell system, J. Power Sources, 193 (2009) 779.

[21] K.T. Park, U.H. Jung, S.U. Jeong, S.H. Kim, Influence of anode diffusion layer properties on performance of direct borohydride fuel cell, J. Power Sources, 162 (2006) 192.

[22] Z. Jusys, R.J. Behm, Borohydride electrooxidation over Pt/C, AuPt/C and Au/C catalysts: Partial reaction pathways and mixed potential formation, Electrochem. Commun., 60 (2015) 9.

* First paper that demonstrates that there are two sources of hydrogen production upon BOR: (i) essentially from the water reduction (HER) below $0 \mathrm{~V}$ vs RHE and (ii) from catalytic decomposition / dissociative adsorption of $\mathrm{BH}_{4}{ }^{-}$above $0 \mathrm{~V}$ vs RHE

[23] A.G. Oshchepkov, G. Braesch, G. Rostamikia, A. Bonnefont, M.J. Janik, M. Chatenet, E.R. Savinova, Insights into the borohydride electrooxidation reaction on metallic nickel from operando FTIRS, on-line DEMS and DFT, Electrochim. Acta, 389 (2021) 138721.

** Insights into the BOR mechanism on metallic Ni electrodes

[24] G. Braesch, A. Bonnefont, V. Martin, E.R. Savinova, M. Chatenet, Borohydride oxidation reaction mechanisms and poisoning effects on $\mathrm{Au}, \mathrm{Pt}$ and Pd bulk electrodes: From model (low) to direct borohydride fuel cell operating (high) concentrations, Electrochim. Acta, 273 (2018) 483.

** Elucidation of the BOR mechanism on Pt, Pd and $\mathrm{Au}$ electrodes, and influence on the operating conditions on the efficiency and pathway of the reaction

[25] M.C.S. Escano, Borohydride electro-oxidation on metal electrodes: structure, composition and solvent effects from DFT, in: Electrochemistry: Volume 14, vol. 14, The Royal Society of Chemistry, 2017, pp. 1-22.

[26] G. Rostamikia, M.J. Janik, Borohydride Oxidation over Au(111): A First-Principles Mechanistic Study Relevant to Direct Borohydride Fuel Cells, J. Electrochem. Soc., 156 (2009) B86.

[27] G. Rostamikia, M.J. Janik, First principles mechanistic study of borohydride oxidation over the Pt(111) surface, Electrochim. Acta, 55 (2010) 1175.

[28] J.A. Herron, J. Scaranto, P. Ferrin, S. Li, M. Mavrikakis, Trends in formic acid decomposition on model transition metal surfaces: A density functional theory study, ACS Catal., 4 (2014) 4434.

[29] P. Ferrin, S. Kandoi, A.U. Nilekar, M. Mavrikakis, Hydrogen adsorption, absorption and diffusion on and in transition metal surfaces: A DFT study, Surf. Sci., 606 (2012) 679.

[30] B.H. Liu, S. Suda, Influences of fuel crossover on cathode performance in a micro borohydride fuel cell, J. Power Sources, 164 (2007) 100.

[31] S. Ould-Amara, J. Dillet, S. Didierjean, M. Chatenet, G. Maranzana, Operating heterogeneities within a direct borohydride fuel cell, J. Power Sources, 439 (2019) 227099.

* Effect of the operating parameters on the performance of CEM-based DBFCs

[32] R.O. Stroman, G.S. Jackson, Y. Garsany, K. Swider-Lyons, A calibrated hydrogenperoxide direct-borohydride fuel cell model, J. Power Sources, 271 (2014) 421.

[33] Z. Wang, J. Parrondo, C. He, S. Sankarasubramanian, V. Ramani, Efficient pH-gradientenabled microscale bipolar interfaces in direct borohydride fuel cells, Nature Energy, 4 (2019) 281.

** Demonstration of BPM in $\mathrm{H}_{2} \mathrm{O}_{2}$-DBFCs, with high-performance and high stability of operation 
[34] Z. Wang, M. Mandal, S. Sankarasubramanian, G. Huang, P.A. Kohl, V.K. Ramani, Influence of Water Transport Across Microscale Bipolar Interfaces on the Performance of Direct Borohydride Fuel Cells, ACS Applied Energy Materials, 3 (2020) 4449.

** The article shows how the mass-transfer influences the apparent performance of $\mathrm{H}_{2} \mathrm{O}_{2}-$ DBFCs

[35] N.A. Choudhury, J. Ma, Y. Sahai, High performance and eco-friendly chitosan hydrogel membrane electrolytes for direct borohydride fuel cells, J. Power Sources, 210 (2012) 358.

* The highest performances reached for a DFBC (of small geometric area)

[36] M. Chatenet, Tailoring membranes, Nature Energy, 4 (2019) 261.

[37] X. Yang, Y. Liu, S. Li, X. Wei, L. Wang, Y. Chen, A direct borohydride fuel cell with a polymer fiber membrane and non-noble metal catalysts, Sci. Rep., 2 (2012) 567.

[38] J. Ma, X. Gao, D. Wang, T. Xue, S. Yang, Effect of cobalt precursors on Co3O4 anodic catalyst for a membrane-free direct borohydride fuel cell, J. Alloys Compd., 724 (2017) 474.

[39] N. Da Mota, D.A. Finkelstein, J.D. Kirtland, C.A. Rodriguez, A.D. Stroock, H.D. Abruna, Membraneless, Room-Temperature, Direct Borohydride/Cerium Fuel Cell with Power Density of Over 0.25 W/cm(2), J. Am. Chem. Soc., 134 (2012) 6076.

[40] A. Serov, A. Aziznia, P.H. Benhangi, K. Artyushkova, P. Atanassov, E. Gyenge, Borohydride-tolerant oxygen electroreduction catalyst for mixed-reactant Swiss-roll direct borohydride fuel cells, J. Mater. Chem. A, 1 (2013) 14384.

* An interesting concept of mixed-reactant DBFC

[41] A. Aziznia, C.W. Oloman, E.L. Gyenge, Experimental advances and preliminary mathematical modeling of the Swiss-roll mixed-reactant direct borohydride fuel cell, J. Power Sources, 265 (2014) 201.

[42] M. Chatenet, F. Micoud, I. Roche, E. Chainet, J. Vondrak, Kinetics of sodium borohydride direct oxidation and oxygen reduction in sodium hydroxide electrolyte - Part II. O-2 reduction, Electrochim. Acta, 51 (2006) 5452.

[43] J. Wang, F. Chen, Y. Jin, Y. Lei, R.L. Johnston, One-Pot Synthesis of Dealloyed AuNi Nanodendrite as a Bifunctional Electrocatalyst for Oxygen Reduction and Borohydride Oxidation Reaction, Advanced Functional Materials, (2017) 1700260.

[44] Q. Wang, F. Chen, Y. Liu, N. Zhang, L. An, R.L. Johnston, Bifunctional Electrocatalysts for Oxygen Reduction and Borohydride Oxidation Reactions Using Ag3Sn Nanointermetallic for the Ensemble Effect, ACS Applied Materials \& Interfaces, 9 (2017) 35701.

[45] J. Wang, F. Chen, Y. Jin, R.L. Johnston, Gold-Copper Aerogels with Intriguing Surface Electronic Modulation as Highly Active and Stable Electrocatalysts for Oxygen Reduction and Borohydride Oxidation, ChemSusChem, (2018).

[46] R. Sgarbi, E.A. Ticianelli, F. Maillard, F. Jaouen, M. Chatenet, Oxygen Reduction Reaction on Metal and Nitrogen-Doped Carbon Electrocatalysts in the Presence of Sodium Borohydride, Electrocatal., 11 (2020) 365.

* Non-PGM catalysts can be remarkably tolerant to the presence of $\mathrm{BH}_{4}{ }^{-}$for the ORR

[47] A.C. Garcia, F.H.B. Lima, E.A. Ticianelli, M. Chatenet, Carbon-supported nickel-doped manganese oxides as electrocatalysts for the oxygen reduction reaction in the presence of sodium borohydride, J. Power Sources, 222 (2013) 305.

[48] R.M.E. Hjelm, C. Lafforgue, R.W. Atkinson, III, Y. Garsany, R.O. Stroman, M. Chatenet, K. Swider-Lyons, Impact of the anode catalyst layer design on the performance of H2O2-direct borohydride fuel cells, J. Electrochem. Soc., 166 (2019) F1218.

* Influence of the structuration of the anode on its performance in a $\mathrm{H}_{2} \mathrm{O}_{2}$-DBFC with PGM-based anodes

[49] D.S.P. Cardoso, D.M.F. Santos, B. Šljukić, C.A.C. Sequeira, D. Macciò, A. Saccone, Platinum-rare earth cathodes for direct borohydride-peroxide fuel cells, J. Power Sources, 307 (2016) 251. 
[50] D.M.F. Santos, T.F.B. Gomes, B. Šljukić, N. Sousa, C.A.C. Sequeira, F.M.L. Figueiredo, Perovskite cathodes for NaBH4/H2O2 direct fuel cells, Electrochim. Acta, 178 (2015) 163.

[51] P.-Y. Olu, F. Deschamps, G. Caldarella, M. Chatenet, N. Job, Investigation of platinum and palladium as potential anodic catalysts for direct borohydride and ammonia borane fuel cells, J. Power Sources, 297 (2015) 492.

* Influence of the structuration of the anode on its performance in a DBFC with PGMbased anodes

[52] G. Braesch, A.G. Oshchepkov, A. Bonnefont, F. Asonkeng, T. Maurer, G. Maranzana, E.R. Savinova, M. Chatenet, Nickel 3D Structures Enhanced by Electrodeposition of Nickel Nanoparticles as High Performance Anodes for Direct Borohydride Fuel Cells, ChemElectroChem, 7 (2020) 1789.

** Influence of the structuration of the anode on its performance in a DBFC with a Nibased anode

[53] Z. Wang, S. Sankarasubramanian, V. Ramani, Reactant-Transport Engineering Approach to High-Power Direct Borohydride Fuel Cells, Cell Reports Physical Science, 1 (2020) 100084. [54] F. Asonkeng, G. Maranzana, J. Proust, M. François, L. Le Joncour, J. Dillet, S. Didierjean, G. Braesch, M. Chatenet, T. Maurer, Synthesis of metallic nanoparticles for heterogeneous catalysis: Application to the Direct Borohydride Fuel Cell, Appl. Catal. A: Gen., 618 (2021) 118117.

[55] A.A. Abahussain, C.P. de Leon, F.C. Walsh, Mass-Transfer Measurements at Porous 3D Pt-Ir/Ti Electrodes in a Direct Borohydride Fuel Cell, J. Electrochem. Soc., 165 (2018) F198.

[56] H. Cheng, K. Scott, Influence of operation conditions on direct borohydride fuel cell performance, J. Power Sources, 160 (2006) 407.

[57] C. Lafforgue, A. Zadick, L. Dubau, F. Maillard, M. Chatenet, Selected review of the degradation of Pt and Pd-based carbonsupported electrocatalysts for alkaline fuel cells: towards mechanisms of degradation, Fuel Cells, 18 (2018) 229.

[58] C. Lafforgue, F. Maillard, V. Martin, L. Dubau, M. Chatenet, Degradation of Carbonsupported Platinum Group Metal Electrocatalysts in Alkaline Media Studied by in situ FourierTransform Infrared Spectroscopy and Identical-Location Transmission Electron Microscopy, ACS Catal., 9 (2019) 5613-5622.

[59] Z.P. Li, Z.X. Liu, H.Y. Qin, K.N. Zhu, B.H. Liu, Performance degradation of a direct borohydride fuel cell, J. Power Sources, 236 (2013) 17.

[60] Y.E. Duan, S. Li, Q. Tan, Y. Chen, K. Zou, X. Dai, M. Bayati, B.B. Xu, L. Dala, T.X. Liu, Cobalt nickel boride nanocomposite as high-performance anode catalyst for direct borohydride fuel cell, Int. J. Hydrogen Energy, (2021).

[61] S. Li, C. Shu, Y. Chen, L. Wang, A new application of nickel-boron amorphous alloy nanoparticles: anode-catalyzed direct borohydride fuel cell, Ionics, 24 (2018) 201.

[62] A. Serov, I.V. Zenyuk, C.G. Arges, M. Chatenet, Hot topics in alkaline exchange membrane fuel cells, J. Power Sources, 375 (2018) 149.

[63] W.E. Mustain, M. Chatenet, M. Page, Y.S. Kim, Durability challenges of anion exchange membrane fuel cells, Energy Environ. Sci., 13 (2020) 2805.

[64] D. Chen, S. Yu, X. Liu, X. Li, Porous polybenzimidazole membranes with excellent chemical stability and ion conductivity for direct borohydride fuel cells, J. Power Sources, 282 (2015) 323.

[65] G. Braesch, Z. Wang, S. Sankarasubramanian, A.G. Oshchepkov, A. Bonnefont, E.R. Savinova, V. Ramani, M. Chatenet, A high performance direct borohydride fuel cell using bipolar interfaces and noble metal-free Ni-based anodes, J. Mater. Chem. A, 8 (2020) 20543

$* \quad$ Influence of the structuration of the anode on its performance in a $\mathrm{H}_{2} \mathrm{O}_{2}$-DBFC with a Ni-based anode 
